Przegląd Prawa Konstytucyjnego

-ISSN 2082-1212--------

DOI 10.15804/ppk.2017.05.16

-Nr 5 (39)/2017--------

\title{
Recenzja
}

\section{Artur Ławniczak, Monarchiczne i republikańskie głowy państwa w Europie, ISBN 978-83-60631-42-3, Kolonia Limited, Wrocław 2011, ss. 400}

Recenzowana praca autorstwa dra hab. Artura Ławniczaka pt. Monarchiczne i republikańskie głowy państwa w Europie podejmuje problematykę miejsca i roli głowy państwa w ustroju politycznym współczesnych państw europejskich. Prezentowana monografia stanowi interesującą analizę pozycji ustrojowej monarchów i republikańskich głów państwa w Europie, choć w ujęciu nieczęsto reprezentowanym w prawie konstytucyjnym. Praca ta stanowi interesujące spojrzenie z punktu widzenia prawa konstytucyjnego na zagadnienie monarchistycznych i republikańskich głów państwa w Europie i niewątpliwie wzbogaca dorobek w tym zakresie.

Monografia stanowi pogłębioną i kompleksową analizę pozycji ustrojowej i roli głowy państwa na tle porównawczym różnych systemów prawnych.

Praca, pod względem strukturalnym, składa się ze wstępu, trzech rozdziałów oraz zakończenia. Pod względem problemowym dzieli się na dwie części - pierwszą, poświęconą europejskiej monarchii, oraz drugą, podejmującą tematykę republikańskiej głowy państwa w Europie. Brak jednak zachowania proporcji w stosunku do poszczególnych części i rozdziałów w książce. Zasadnicza część książki poprzedzona jest stosunkowo krótkim, bo trzy stronnicowym wstępem, w szczególności w odniesieniu do rozmiarów i objętości poszczególnych części pracy. Autor, przechodząc od rozważań teoretycznych 
dotyczących przedstawienia w rozdziale I cech charakterystycznych monarchii i republiki, skupia się w kolejnych rozdziałach na konstytucyjnych uregulowaniach w państwach europejskich w zakresie pozycji kompetencji monarchów i prezydentów w systemie organów państwowych. W rozdziale I poza scharakteryzowaniem cech istotnych monarchii i republiki przedstawia jednoosobowe i kolektywne formy głowy państwa, występujące w monarchiach i republikach europejskich. Nie są to zagadnienia, które często są analizowane w prawie konstytucyjnym ${ }^{1}$. Autor zwraca uwagę na sui generis głowę państwa w Konfederacji Szwajcarskiej oraz Suwerennym Rycerskim Zakonie Szpitalników św. Jana Jerozolimskiego.

W zasadniczej części monografii autor przedstawia pozycję ustrojową głowy państwa odpowiednio w systemie monarchicznym, jak i republikańskim. Rozdział II i III, dotyczący odpowiednio właśnie monarchicznych oraz republikańskich głów państwa, oparty jest na analogicznej konstrukcji. Wychodząc od zagadnień terminologicznych i definicyjnych, w których autor posługuje się również własnymi definicjami, przechodzi do rozważań dogmatyczno-prawnych dotyczących głów państwa w konstytucjach wybranych państw europejskich.

W rozdziale poświęconym monarchicznym głowom państwa autor przedstawia funkcjonowanie monarchii w Europie w XX wieku, m.in. w Zjednoczonym Królestwie Wielkiej Brytanii i Irlandii Północnej, Królestwie Szwecji, nie pomijając trudnych do zakwalifikowania państw tj. Watykan czy Księstwo Andory. Co interesujące autor w monografii podkreśla, że w modelowych monarchiach cechą charakterystyczną jest dziedziczność i dożywotność ${ }^{2}$ sprawowania władzy, a monarchia elekcyjna stanowi rodzaj odstępstwa od zasady, którą trudno jednoznacznie zakwalifikować w ramach danej formy rządów. Przy czym jak słusznie zauważam, w przypadku dożywotnich dyktatorów, nie możemy mówić o specyficznym rodzaju monarchii, a raczej o zdeformowanym systemie rządów republikańskich. Autor dokonuje analizy państw monarchicznych w oparciu o ich nazwy, dzieląc je na królestwa i księstwa. Zauważa jednak problem z umiejscowieniem w monarchiczno-

Dla porównania zob.: T. Słomka, Model głowy państwa w Europie Środkowowschodniej w okresie realnego socjalizmu, [w:] Przestrzeń polityki i spraw wyznaniowych, red. B. Górowska, Warszawa 2004.

2 A. Ławniczak, Monarchiczne i republikańskie gtowy państwa, Wrocław 2011, s. 19. 
-republikańskiej klasyfikacji: Andory, Watykanu oraz Zakonu Maltańskiego. Autor zauważa trudności w określeniu formy państwowości w przypadku współksięstwa Andory, ze zwierzchnictwem biskupa hiszpańskiego miasta Seu de Urgel oraz francuskiego Prezydenta. Z uwagi na fakt, że głową państw wspólnie z biskupem jest prezydent, pojawiają się w doktrynie głosy by uznać Andorę za republikę ${ }^{3}$. Jak słusznie zauważa autor nie jest to słuszne z uwagi na tytulaturę wpsółwładców Andory jako książąt. Ponadto, art. 1 konstytucji Andory określa oficjalną nazwę jako Księstwo Andory, będące współksięstwem parlamentarnym ${ }^{4}$. Do szczególnie interesujących należą rozważania autora nad kwestiami państwowości Watykanu i Zakonu Maltańskiego, określając je mianem „szczególnych, specyficznych form państwa” występujących obok monarchii i republiki, do których kategorii zalicza m.in. pozaeuropejskie kalifaty i emiraty ${ }^{5}$. W przypadku Watykanu autor wprawdzie zastanawia się nad zakwalifikowaniem go jako republiki z uwagi na brak w tytulaturze występowania określeń charakterystycznych dla monarchii. Jednak całokształt struktury organizacyjnej państwa- miasta Watykanu, kompetencji papieża, dożywotność sprawowania przez niego władzy oraz form działania tego państwa przemawiają za jego monarchicznością.

W rozdziale II autor przedstawia m.in. pozycje ustrojową monarchii w Europie, funkcję monarchii oraz jej relację w ramach Monteskiuszowskiego podziału władzy, sukcesji i odpowiedzialności monarchów. Analiza stosunku władzy ustawodawczej, w tym liczby izb parlamentu do funkcjonowania monarchii daje asumpt do rozważań dotyczących pozostawienia dwóch izb parlamentarnych w monarchiach, jak i roli i kompetencji monarszych na tle pozostałych organów państwowych, w myśl zasady, że monarcha panuje a nie rządzi ${ }^{6}$. Autor podkreśla, poza Watykanem, Monakiem i Liechtensteinem, symboliczną rolę monarchy we współczesnych monarchiach m.in. otwierania posiedzenia parlamentu, rozpisywanie wyborów do parlamentu, reprezentowaniu państwa na arenie międzynarodowej. Autor w pracy podkreśla nie tylko prawną i polityczną rolę głowy państwa, zaznaczając jej obecną sym-

3 Ibidem, s. 61.

4 Art. 1 ust. 1 i ust. 4 Konstytucji Księstwa Andory, tł.: M. Bobiński, wstęp: M. Zubik, Warszawa 2014, s. 83.

5 A. Ławniczak, op.cit., s. 63.

6 Ibidem, s. 82 . 
boliczną rolę. Autor podkreśla pozycję monarchy w ramach polityki zagranicznej i obronności państwa. W tym ostatnim przypadku, pomimo, że polityka dotycząca obrony leży w gestii rządu, to jednak pozostawiono monarchę tytulaturę najwyższego dowódcy. Zakończenie rozdziału II dotyczy odpowiedzialności monarchów oraz przedstawia analizę znaczenia monarchów we współczesnych monarchiach, podkreślając utożsamianie przez społeczeństwo monarchy z samym państwem ${ }^{7}$. Zasadnym wydaje się być przedstawienie w tym miejscu, a nie tylko w zakończeniu monografii, pogłębionej analizy znaczenia i pozycji monarchy we współczesnych systemach politycznych. Autor podkreśla ograniczenie kompetencji monarchy względem rządu. W większości europejskich monarchii, jak słusznie zauważa autor, rola monarchy polega na doradzaniu a następnie akceptowaniu decyzji rządowych, nawet jeśli z nimi się nie zgadza. Jak podkreśla A. Ławniczak, obecnie w doktrynie przyjmuje się, że współczesne monarchie nie są monarchiami rzeczywistymi, a kompetencje monarchy maja charakter czysto formalny i symboliczny ${ }^{8}$. Zauważa przy tym zwiększenie znaczenia i kompetencji głów państwa $\mathrm{w}$ systemach republikańskich w porównaniu z monarchami, którego radykalnym przykładem jest prezydent Stanów Zjednoczonych. Co ciekawe, autor dostrzega, że w przypadku europejskich księstw, jak ma to miejsce w Księstwie Monako oraz Liechtensteinu, pozycja jednoosobowej głowy państwa jest inna, o znacznie szerszych kompetencjach niż w królestwach. W związku z tym autor podkreśla, że ustroje panujące w tych państwach trudno nazwać parlamentarnymi lub demokratycznymi. Jednocześnie w monografii autor podkreśla konsolidującą społeczeństwo rolę jednoosobowej głowy państwa. Co niewątpliwie pozwala na wyróżnienie pozycji monarchy względem prezydentów w systemach republikańskich.

Rozdział III strukturalnie odpowiada rozdziałowi II, z tym że dotyczy on głowy państwa w europejskich republikach. Przechodząc od problemu podziału władzy i pojęcia suwerena, A. Ławniczak dokonuje analizy pozycji ustrojowej głowy państwa w ramach Monteskiuszowskiego trójpodziału władzy. Autor zaznacza silniejszą niż w przypadku monarchów pozycję i funkcję republikańskiej głowy państwa. Podkreśla jednocześnie kompetencje republi-

Ibidem, s. 168.

8 Ibidem, s. 163 i cyt. lit. 
kańskich głów państwa w zakresie rozpisywania wyborów, przyjmowania przysięgi czy wyznaczania pierwszego posiedzenia parlamentu. A. Ławniczak analizuje też zagadnienie ilości liczb parlamentu w odniesieniu do głowy państwa oraz struktury terytorialnej. W odniesieniu do republikańskich głów państwa autor przedstawia problematykę suwerena w republikach, a także relację głowy państwa w ramach władzy wykonawczej, ustawodawczej oraz sądowniczą oraz zagadnienia ich reelekcji i odpowiedzialności.

W odróżnieniu od części dotyczącej monarchii, autor porusza w jednym z podrozdziałów rozdziału III zagadnienia pozycji głowy państwa w demokracjach bezpośrednich, chociaż w monarchiach formy demokracji bezpośredniej też występują. Ponadto, w rozdziale tym autor przedstawia również zagadnienie odpowiedzialności politycznej i konstytucyjnej prezydentów. Rozróżnienia tych odpowiedzialności autor nie dokonał w przypadku monarchów. Autor podkreśla, że ponoszenie odpowiedzialności przez prezydenta stanowi przejaw republikańskości. Ostatnia część rozdziału III dotyczy znaczenia pozycji i funkcji głowy państwa we współczesnych systemach republikańskich. Podrozdział ten stanowi generalne podsumowanie procesów zachodzących w państwach republikańskich oraz roli w nich prezydentów. Autor wyróżnia konstytucyjno-politologiczne modele władzy prezydenckiej w państwach europejskich w oparciu o kompetencje głów państwa, sposobu ich wybierania oraz pociągania ich do odpowiedzialności. Zwraca przy tym uwagę na problematykę wyboru głowy państwa w poszczególnych republikach, a tym samym legitymizacji jaką daje wybór prezydenta bądź to przez parlament bądź to $\mathrm{w}$ wyborach powszechnych ${ }^{9}$. W tym ostatnim przypadku kompetencje prezydenta są dużo większe, co daje asumpt do ukształtowania republiki prezydenckiej, w której paradoksalnie, jak zauważa autor, tendencje monarchistyczne uwidaczniają się bardziej niż w niejednej monarchii ${ }^{10}$. Autor dochodzi do wniosków, że republiki prezydenckie przypominają bardziej tradycyjne, dawne monarchie. Podkreśla on tendencje do kształtowania się w państwach - postradzieckich republikach ZSRR systemów semiprezydenckich czy prezydencjalistycznych. Autor zauważa natomiast, że w przypadku państw Europy Zachodniej model stanowią pluralistyczne demokracje

9 Przykład Polski - kompetencje rządu a prezydenta.

10 A. Ławniczak, op.cit., s. 361. 
pośrednie o systemie parlamentarno-gabinetowym ${ }^{11}$. Jednakże autor zauwa$\dot{z ̇ a}$ że pozycja prezydenta ma też wymiar symboliczny, polegająca na odgrywaniu specyficznej, konsolidacyjnej roli w społeczeństwie danego państwa i jego historii.

W zakończeniu autor przedstawia wnioski odnośnie znaczenia głów państwa w republikach i monarchiach, podkreślając premieryzację obu ustrojów. Autor wykazuje, że pomimo przemian ustrojowo-politycznych na kontynencie europejskim wciąż utrzymuje się dychotomiczny podział na państwa z monarchiczną albo z republikańską. Jednocześnie jak trafnie zauważa, „zarówno w wymiarze doktrynalnym, jak i instytucjonalnym"12 doszło do konwergencji tych organów. Uwzględnienie przez autora perspektywy historycznej niewątpliwie wzbogaca opracowania z zakresu prawa konstytucyjnego dotyczących pozycji ustrojowej głowy państwa.

Wykorzystanie literatury polskojęzycznej, jak i obcojęzycznej daje czytelnikowi całościowy obraz pozycji ustrojowej głów państwa w Europie. W monografii wykorzystano prawie sześćset pozycji bibliograficznych, głównie polskojęzycznych, choć nie brak też źródeł zagranicznych. Pomimo wręcz imponującej bibliografii, w tym wykorzystaniu aktów prawnych, jak i opracowań naukowych, można by się zastanowić czy autor odnosząc się do danych państw nie powinien przywiązać większej uwagi do publikacji źródłowych w wybranych państwach. Jednocześnie autor wykorzystuje w pracy czasopisma popularne, w tym przede wszystkim czasopisma narodowo-konserwatywne tj. „Najwyższy Czas! Tygodnik konserwatywno-liberalny, Nowe Państwo".

Monografia stanowi istotny i wartościowy wkład odnośnie kompleksowego ukazania pozycji i roli głowy państwa we współczesnej Europie. Należy bowiem podkreślić, że nie jest wiele monografii naukowych zajmujących się wyłącznie problematyką głowy państwa, a w szczególności holistycznego przedstawienia monarchicznych głów państwa. Do najbardziej wartościowych elementów pracy należy przedstawienie relacji pomiędzy poszczególnymi władzami i wyłaniającymi się na tym tle rozważaniami dotyczącymi funkcji i kompetencji głowy państwa.

11 Ibidem, s. 362-363.

12 Autor przedstawia zbliżanie się tych dwóch organów. idem, s. 368. 
Praca stanowi kompleksowe spojrzenie na problematykę znaczenia monarchów i prezydentów w systemach organów państwowych oraz jak, i czy w ogóle, doszło do procesu zbliżenia się tych dwóch form w państwach europejskich. Praca bez wątpienia stanowi ciekawą pozycję w literaturze z zakresu współczesnych systemów politycznych. Monografia ta stanowi jedną z czołowych opracowań dotyczących analizy konstytucyjnego znaczenia i funkcji głowy państwa w ustroju politycznym europejskich państw.

Anna Chodorowska Uniwersytet Zielonogórski 